\title{
ON THE CREEP DEFORMATION OF A CAST NEAR GAMMA TiAl ALLOY Ti-48Al-1Nb
}

\author{
R. W. HAYES ${ }^{1}$ and B. LONDON ${ }^{2}$ \\ 'Metals Technology, Inc., 19801 Nordhoff Street, Northridge, CA 91324 and ${ }^{2}$ Howmet Corporation, \\ Applied Research Division, 1500 South Warner Street, Whitehall, MI 49461-1895, U.S.A.
}

\begin{abstract}
The steady-state creep deformation behavior of a cast two phase gamma TiAl alloy having the composition $\mathrm{Ti}-48 \mathrm{Al}-1 \mathrm{Nb}(\mathrm{at} . \%)$ has been studied. Tension creep tests using the stress increment technique $\left(\sigma_{1}<\sigma_{2}<\sigma_{3}\right)$ were conducted over the temperature range of $704-850^{\circ} \mathrm{C}$ at constant initial applied stress level of 103.4-241.3 MPa. The activation energy for creep over the temperature and stress regime of this study varied from $317.5 \mathrm{~kJ} / \mathrm{mol}(137.8 \mathrm{MPa}$ ) up to $341.0 \mathrm{~kJ} / \mathrm{mol}$ (206.8 MPa) with an average value of $326.4 \mathrm{~kJ} / \mathrm{mol}$. This is well within the range of values previously measured for gamma TiAl alloys where creep controlled by volume diffusion has been suggested as rate controlling. The stress exponents measured were 5.0 at $704^{\circ} \mathrm{C}, 4.9$ at $750^{\circ} \mathrm{C}, 4.7$ at $800^{\circ} \mathrm{C}$ and 4.46 at $850^{\circ} \mathrm{C}$. Using the activation energy of $326.4 \mathrm{~kJ} / \mathrm{mol}$, the temperature compensated steady-state creep rate was plotted against $\log$ stress with all temperatures collapsing onto a single line having a slope equal to 4.95 . Using conventional creep analysis, this value of the stress exponent can be taken as suggestive of dislocation climb controlled power law creep as the operative deformation mechanism within the stress and temperature regime of the present study. The boundary separating the lamellar grains in two phase gamma TiAl alloys having the duplex microstructure may be a very important aspect of this microstructure with respect to creep deformation resistance. The interlocking $\gamma / \alpha_{2}$ laths making up these boundaries are expected to be very resistant to grain boundary sliding which may contribute to creep deformation in the dislocation creep regime. Finally, some previous observations along with a comparison of the creep behavior of the Ti-48Al-1Nb alloy to that of a Ti-50.3Al binary have been discussed in terms of the pre-exponential constant $A$ in the power law creep equation. TiAl alloys having similar stress and temperature dependencies but differing steady-state strain rates over comparable stress-temperature regimes may be rationalized on the basis of differing power law creep constants which may reflect differences in stacking fault energies.
\end{abstract}

Résumé- - On étudie la déformation par fluage en régime permanent d'un alliage TiAl gamma biphasé coulé ayant la composition $\mathrm{Tj}-48 \mathrm{Al}-1 \mathrm{Nb}$ (en \% atomique). Des essais de fluage, par la technique de l'incrément de contrainte $\left(\sigma_{1}<\sigma_{2}<\sigma_{3}\right)$, sont effectués sur une gamme de températures allant de $704850^{\circ} \mathrm{C}$ pour des niveaux initiaux constants de la contrainte appliquée allant de 103,4 MPa-24l,3 MPa. L'énergie d'activation du fluage dans la gamme de contraintes et de températures de cette étude varie entre $317,5 \mathrm{~kJ} / \mathrm{mol}$ $(137,8 \mathrm{MPa})$ et $341,0 \mathrm{~kJ} / \mathrm{mol}(206,8 \mathrm{MPa})$ avec une valeur moyenne de $326,4 \mathrm{~kJ} / \mathrm{mol}$. Ces résultats sont bien dans le domaine des valeurs déjà mesurées pour les alliages TiAl gamma où l'on supposait que la vitesse de fluage était contrôlée par la diffusion en volume. Les exposants de contrainte mesurés sont de 5,0 à $704^{\circ} \mathrm{C}, 4,9$ à $750^{\circ} \mathrm{C}, 4,7$ à $800^{\circ} \mathrm{C}$ et 4,46 à $850^{\circ} \mathrm{C}$. En utilisant une energie d'activation de $326,4 \mathrm{~kJ} / \mathrm{mol}$, la vitesse de fluage en regime permanent compensée pour la température est portée en fonction du logarithme de la contrainte avec toutes les températures donnant une seule ligne de pente 4,95. Par une analyse classique du fluage, on peut considérer que cette valeur de l'exponsant de contrainte suggère un fluage contrôlé par la montée des dislocations qui serait le mécanisme actif dans la gamme de températures et de contraintes de cette étude. La frontiére qui sépare les grains lamellaires dans l'alliage TiAl gamma biphasé présentant la microstructure duplex peut être un aspect très important de cette microstructure par rapport à la résistance à la déformation par fluage. On s'attend à ce que les lattes imbriquées $\gamma / \alpha_{2}$ qui constituent ces frontières soient très resistantes au glissement intergranulaire, ce qui peut contribuer a la déformation par fluage dans le régime de fluage par dislocations. Enfin, on discute quelques observations antérieures en comparant le fluage de l'alliage $\mathrm{Ti}-48 \mathrm{Al}-1 \mathrm{Nb}$ et celui de l'alliage binaire $\mathrm{Ti}-50,3 \mathrm{Al}$ en s'intéressant au facteur constant preexponentiel $A$ de l'équation de fluage. Des alliages TiAl qui ont des dépendances identiques vis à vis de la température et de la contrainte, mais qui diffèrent par les vitesses de déformation en régime permanent dans des domaines comparables de températures et de contraintes peuvent être classes a partir des constantes. A differentes de la loi de fluage, ce qui pourrait refleter des différences dans l'énergie de défaut d'empilement.

Zusammenfassung - Das stationäre Kriechverhalten einer gegossenen zweiphasigen Gamma-TiAl-Legierung der Zusammensetzung Ti-48Al-1 Nb (in At.\%) wird untersucht. Hierzu werden mit der Methode des Spannungsanstieges $\left(\sigma_{1}<\sigma_{2}<\sigma_{3}\right)$ Kriechversuche unter Zugbelastung im Temperaturbereich zwischen $704-850^{\circ} \mathrm{C}$ und den zu Anfang gleichen Spannungswerten von 103,4-241,3 MPa durchgeführt. Die Kriechaktivierungsenergie variiert in diesem experimentellen Bereich zwischen 317,5 (bei 137,8 MPa) und $341 \mathrm{~kJ} / \mathrm{Mol}$ (bei 206,8 MPa); ein mittlerer Wert ist $326,4 \mathrm{~kJ} / \mathrm{Mol}$. Diese Werte entsprechen gut früher gemessenen, die einem durch Volumdiffusion gesteuerten Mechanismus zugeschrieben wurden Die gemessenen Spannungsexponenten betragen 5,0 bei $704^{\circ} \mathrm{C}, 4,9$ bei $750^{\circ} \mathrm{C}, 4,7$ bei $800^{\circ} \mathrm{C}$ und 4,46 bei $850^{\circ} \mathrm{C}$. Mit der bestimmten Aktivierungsenergie von $326,4 \mathrm{~kJ} / \mathrm{Mol}$ wird die temperaturkompensierte 
stationäre Kriechrate über dem Logarithmus der Spannung aufgetragen, wobei die Daten sämtlicher Temperaturen auf eine Linie mit einer Steigung von 4,95 fallen. Dieser Wert des Spannungsexponenten kann als Hinweis auf ein durch Versetzungsklettern gesteuertes Potenzgesetzkriechen gewertet werden. Die Grenze, die die lamellaren Körner in diesen zweiphasigen Gamma-TiAl-Legierungen mit Duplexstruktur trennt, kann ein sehr wichtiger Teil der Mikrostruktur im Hinblick auf den Kriechwiderstand sein. Die ineinander verzahnten $\gamma / \alpha_{2}$-Latten, die diese Grenzen bilden, widerstehen voraussichtlich der Korngrenzgleitung beträchtlich; das kann zur Kriechverformung im Bereich des Versetzungskriechens beitragen. Schließlich werden einige frühere Beobachtungen zusammen mit einem Vergleich zwischen dem Kriechverhalten dieser Legierung und dem der binären Legierung $\mathrm{Ti}-50,3 \mathrm{Al}$ diskutiert anhand der präexponentiellen Konstanten $\boldsymbol{A}$ in er Gleichung des Potenzgesetzkriechens. TiAl-Legierungen, die ähnliche Spannungs und Temperaturabhängigkeiten in vergleichbaren Spannungs- und Temperaturbereichen aufweisen, jedoch unterschiedliche stationäre Verformungsraten, können auf der Grundlage unterschiedlicher Konstanten des Potenzgesetzkriechens (hinweisend auf verschiedene Stapelfehlerenergien) verstanden werden.

\section{INTRODUCTION}

The intermetallic compound TiAl having the $\mathrm{Ll}_{0}$ crystal structure with a f.c.t. symmetry designated as gamma $(y)$ has the potential of becoming a high temperature structural material for applications such as in gas turbine jet engines.

In a recent study, Huang and Hall discuss the deformation and fracture of binary $\mathrm{TiAl}$ base alloys [1]. The highest ductility at room temperature is found in binary $\mathrm{TiAl}$ alloys having $\mathrm{Al}$ concentrations ranging from 46 to 51 at. $\%$ with the peak occurring at about 48 at. \% $\mathrm{Al}$ [1]. In addition to $\mathrm{Al}$ concentration, heat treatment plays a major role in determining the ductility of these alloys at room temperature. Heat treatments in the two phase alpha plus gamma phase field result in duplex microstructures consisting of a mixture of primary gamma grains and lamellar regions consisting of alternate gamma $(\gamma)$ and alpha-2 $\left(\alpha_{2}\right)$ laths [1]. A detailed description of these microstructures and their crystallographic orientation relationships can be found in numerous recent papers [1-4]. It is important to point out that it is the duplex microstructure which exhibits the highest room temperature ductilities in the two phase $\gamma \mathrm{TiAl}$ alloys. Thus, these microstructures are the types which are the primary focus of research programs, aimed at a more fundamental understanding of the mechanical behavior of $\gamma \mathrm{TiAl}$ intermetallic alloys. The major goal at present is to improve upon the room temperature strength and ductility of $\gamma \mathrm{TiAl}$ while maintaining the high temperature creep resistance needed for their intended application.

To date, most of the work reported in the literature on the mechanical behavior of $\gamma \mathrm{TiAl}$ focuses on wrought material. However, recent ongoing research at Howmet Corporation (Whitehall, Mich.) has shown that casting is a viable method of producing $\gamma \mathrm{TiAl}$. Recent results of mechanical property evaluations of several cast gamma TiAl compositions have demonstrated properties equal to those of their wrought counterparts [5].

The purpose of this study is to focus on the high temperature steady-state creep deformation behavior of a cast two phase $\gamma \mathrm{TiAl}$ alloy which has been given a heat treatment intended to maximize room temperature ductility. The composition selected for the present study is very similar to the composition of a wrought binary TiAl alloy studied in creep by Martin et al. previously [6]. We are then able to compare the high temperature creep deformation behavior of these two materials with the intent on understanding creep deformation of cast $\gamma$ TiAl.

\section{EXPERIMENTAL}

\subsection{Material}

The material selected for the present study is a two phase $\gamma \mathrm{TiAl}$ alloy having the nominal composition $\mathrm{Ti}-48 \mathrm{Al}-1 \mathrm{Nb}$ in at.\%. The specific composition in wt $\%$ is given in Table 1 . It was intended to keep the composition of this material simple therefore providing a model $\mathrm{Ti}-48 \mathrm{Al} \gamma$ alloy suitable for the study of basic deformation processes. The addition of $\mathrm{Nb}$ to $\gamma \mathrm{TiAl}$ has been shown to increase the oxidation resistance and also decrease the ductility of $\mathrm{Ti}-48 \mathrm{Al}$ at room temperature [7].

The Ti-48Al-1 Nb was melted into $12.70 \mathrm{~mm}$ dia. by $127 \mathrm{~mm}$ long cast rods at Howmet Corp., Whitehall, Mich. in their induction skull remelting (ISR) unit. The cast rods were then HIPed at $1260^{\circ} \mathrm{C} / 172.35 \mathrm{MPa}$ for $4 \mathrm{~h}$. X-ray radiographs taken of the rods after HIPping, indicated good sound material with no evidence of internal porosity. The rods were then heat treated at $1300^{\circ} \mathrm{C}$ for $10 \mathrm{~h}$ followed by gas fan cooling to room temperature. For the $\mathrm{Ti}-48 \mathrm{Al}$ composition, this heat treatment results in a thermally stable duplex microstructure consisting of a mixture of equiaxed primary gamma grains and lamellar regions containing alternate $\gamma$ and $\alpha_{2}$ laths [1]. This type of microstructure has also resulted in the highest room temperature ductilities measured in cast $\gamma$ TiAl two phase alloys as well [5]. No subsequent heat treatments were given to the cast rods following the $1300^{\circ} \mathrm{C}$ heat treatment.

Table 1. Chemical composition of cast $\mathrm{Ti}-48 \mathrm{Al}-1 \mathrm{Nb}$ in $w t^{\%}$

\begin{tabular}{ccccccc}
\hline $\mathrm{Ti}$ & $\mathrm{Al}$ & $\mathrm{Nb}$ & $\mathrm{H}$ & $\mathrm{O}$ & $\mathrm{N}$ & $\mathrm{C}$ \\
63.10 & 33.80 & 2.50 & $6 \mathrm{ppm}$ & 0.09 & 0.01 & 0.018 \\
\hline
\end{tabular}




\subsection{Specimens and creep tests}

Buttonhead specimens were fabricated by means of low stress plunge grinding on grinders using crush formed wheels. The specimens contained shoulders for placement of the high temperature creep extensometer. The gage section of the specimen measured $5.08 \mathrm{~mm}$ dia. by $30.48 \mathrm{~mm}$ long.

Creep tests were conducted in Satec systems M3 type constant load creep machines having a lever arm ratio of $16: 1$. The creep tests were conducted in air over the temperature range of $704-850^{\circ} \mathrm{C}$ at constant initial applied stress levels ranging from 103.4 up to 241.3 $\mathrm{MPa}$. In this program the incremental stress technique was utilized to obtain the creep data. Upon application of the first stress $\sigma_{1}$, primary followed by steady-state creep was obtained. Following a period well into steady-state creep, the stress was increased from the initial level $\sigma_{1}$, to a new level $\sigma_{2}$, resulting in another increment of primary creep which settled into steady-state. Again, following a period well into steady-state, the stress was increased to the third and final stress level $\sigma_{3}$. An accurate measurement of the steady-state creep rate was obtained at each stress level prior to the increase in stress to the next level. The specimen temperatures were measured by placement of two high temperature thermocouples on the gage section of each specimen. A 30 min soak period to allow complete specimen temperature equilibration was given prior to beginning each creep test. Each specimen was tested at a single temperature. All test temperatures were controlled to within $\pm 2^{\circ} \mathrm{C}$ of the intended test temperature. The creep strains were measured using dual dial gage averaging type extensometers having a strain resolution of $10^{-5}$. The extensometers were attached to shoulders machined onto the creep specimens. All creep strains and strain rates reported are based on a specimen gage length of $30.48 \mathrm{~mm}$. All creep tests were conducted in air. In addition to the incremental stress creep tests, a few specimens were tested at a given temperature at an initial applied stress level equal to $\sigma_{3}$ of the incremental stress creep test at the same temperature. This provides a direct comparison of the primary and steady-state creep behavior in order to assess the effects of prior deformation history on the creep behavior

\section{RESULTS}

\subsection{Microstructure}

Figure 1 shows an optical micrograph of the microstructure following the $1300^{\circ} \mathrm{C}$ heat treatment. The microstructure consists of equiaxed primary $\gamma$ grains along with regions of lamellar structure containing alternate $\gamma$ and $\alpha_{2}$ laths and is referred to as the duplex microstructure [1]. The details of the transformation of the $\alpha$ grains leading to the formation of the lamellar structure have been discussed previously [2-4]. A very interesting aspect of the duplex microstructure, is the boundary where two

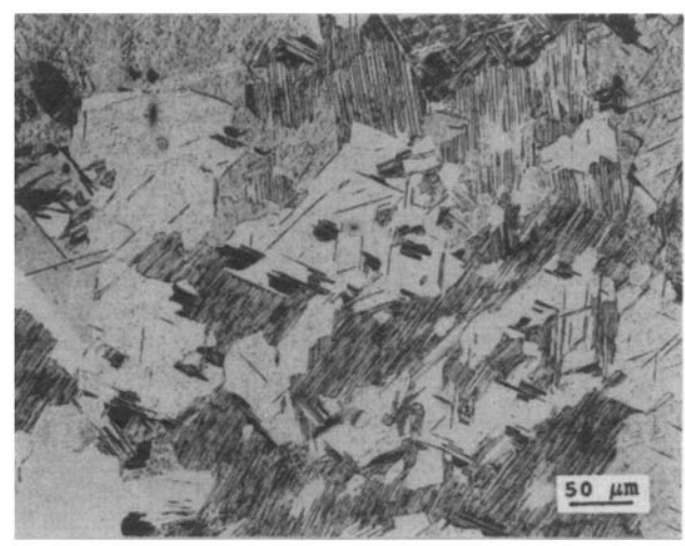

Fig. 1. Optical micrograph of cast $\mathrm{Ti}-48 \mathrm{Al}-\mathrm{INb}$ microstructure following heat treatment at $1300^{\circ} \mathrm{C}$ for $10 \mathrm{~h}$.

lamellar grains meet. As shown in Fig. 1, many boundaries between lamellar grains consist of interlocking laths rather than a smooth boundary separating the two grains. In light of the importance of grain boundaries in high temperature creep, this feature may be a very important aspect of the microstructure. The grain size of the $\mathrm{Ti}-48 \mathrm{Al}-1 \mathrm{Nb}$ ranges from about 15 to $50 \mu \mathrm{m}$ similar to the microstructure of the $\mathrm{Ti}-48 \mathrm{Al}$ binary alloy heat treated at $1350^{\circ} \mathrm{C}$ reported by Huang and Hall [1]. The optical microstructure of the $\mathrm{Ti}-48 \mathrm{Al}-1 \mathrm{Nb}$ was revealed using an etch consisting of $50 \mathrm{cc} \mathrm{H}_{2} \mathrm{SO}_{4}, 20 \mathrm{cc} \mathrm{HNO}_{3}$ and $6 \mathrm{cc}$ $\mathrm{HF}$ following Dogan et al. [8].

\subsection{Creep deformation}

The creep parameters of temperature and stress employed in this study all resulted in creep curves

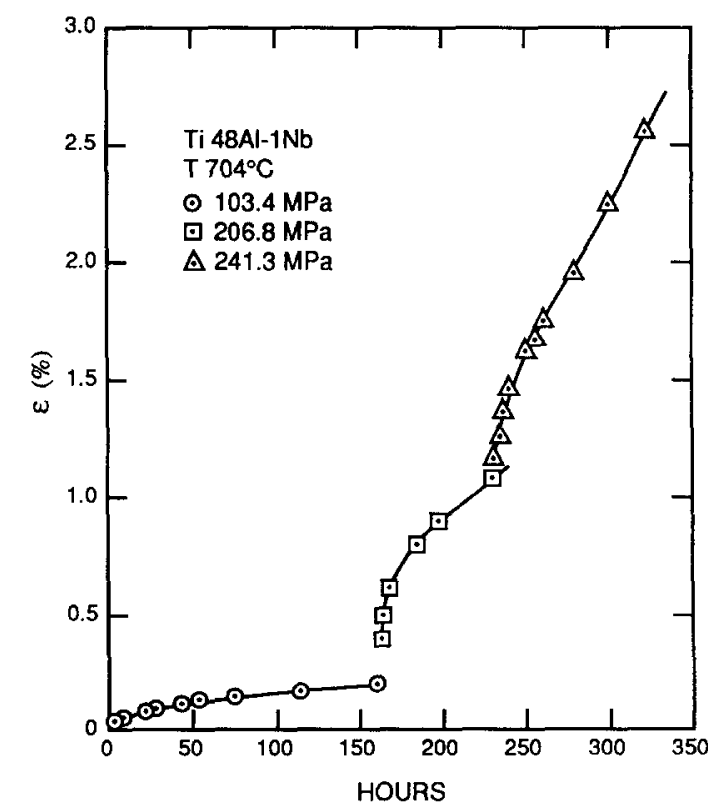

Fig. 2. Creep response of $\mathrm{Ti}-48 \mathrm{Al}-1 \mathrm{Nb}$ at $704^{\circ} \mathrm{C}$ as a function of incremental stress increase from $103.4 \mathrm{MPa}$ up to $241.3 \mathrm{MPa}$. 
Table 2. Summary of creep data for cast $\mathrm{Ti}-48 \mathrm{Al}-1 \mathrm{Nb}$

\begin{tabular}{cccc}
\hline$T$ & $\begin{array}{c}\sigma \\
\left({ }^{\circ} \mathbf{C}\right)\end{array}$ & $\begin{array}{c}\dot{\varepsilon}_{\min } \\
\left(\mathbf{H R}^{-1}\right)\end{array}$ & $\dot{\varepsilon} \cdot \mathrm{e}^{Q / R T}$ \\
\hline 704 & 103.4 & $2.2 \times 10^{-6}$ & $6.2202 \times 10^{11}$ \\
704 & 206.8 & $5.7 \times 10^{-5}$ & $1.6116 \times 10^{13}$ \\
704 & 241.3 & $1.21 \times 10^{-4}$ & $3.4211 \times 10^{13}$ \\
750 & 103.4 & $1.28 \times 10^{-5}$ & $5.9412 \times 10^{11}$ \\
750 & 206.8 & $3.33 \times 10^{-4}$ & $1.5456 \times 10^{13}$ \\
750 & 241.3 & $1.0 \times 10^{-3}$ & $4.6416 \times 10^{13}$ \\
800 & 103.4 & $7.22 \times 10^{-5}$ & $5.6048 \times 10^{11}$ \\
800 & 172.35 & $5.9 \times 120^{-4}$ & $4.5801 \times 10^{12}$ \\
800 & 206.8 & $2.4 \times 10^{-3}$ & $1.8631 \times 10^{13}$ \\
850 & 103.4 & $4.0 \times 10^{-4}$ & $6.0898 \times 10^{11}$ \\
850 & 172.35 & $5.0 \times 10^{-3}$ & $7.6123 \times 10^{12}$ \\
850 & 206.8 & $1.62 \times 10^{-2}$ & $2.4664 \times 10^{13}$ \\
$800^{\mathrm{a}}$ & 206.8 & $2.8 \times 10^{-3}$ & $2.1736 \times 10^{13}$ \\
\hline
\end{tabular}

${ }^{\mathrm{a}}$ Single stress.

exhibiting a primary stage of creep followed by a well defined steady-state strain rate $\dot{\varepsilon}_{s}$. An example of the typical creep response of the Ti-48Al-1Nb is presented in Fig. 2 where the creep response is shown at $704^{\circ} \mathrm{C}$ as a function of increasing applied stress level. As expected, the steady-state strain rate increases progressively with increasing stress level at constant temperature. This pattern is also expected with increasing temperature at constant stress and is also observed in the present study. A summary of all the creep parameters and resulting steady-state creep rates is presented in Table 2. Also included in Table 2 is

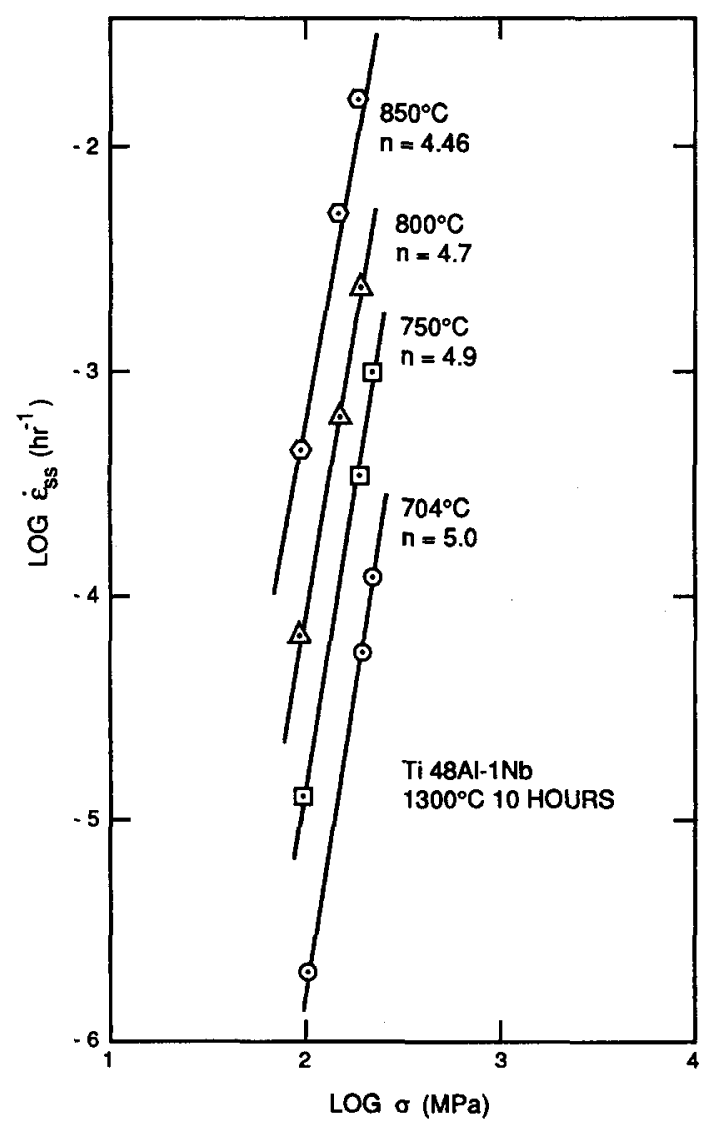

Fig. 3. Plots of stress dependence of steady-state creep rate of $\mathrm{Ti}-48 \mathrm{Al}-1 \mathrm{Nb}$ at $704,750,800$ and $850^{\circ} \mathrm{C}$. the temperature compensated steady-state strain rate which is discussed later in the paper.

From the creep data presented in Table 2, plots of the stress and temperature dependence of the steadystate strain rate can be made. Figure 3 presents the steady-state creep rate plotted against the applied stress on $\log$-log scales. The slopes of these plots correspond to the apparent stress exponent. As shown in Figure 3, the apparent stress exponent ranges from 5.0 at $704^{\circ} \mathrm{C}$ to 4.46 at $850^{\circ} \mathrm{C}$. These results are in almost identical agreement with the apparent stress exponents previously reported for a $\mathrm{Ti}-50.3 \mathrm{Al}$ binary and a $\mathrm{Ti}-48.7 \mathrm{Al}-2.2 \mathrm{~W}$ ternary where values of 4.0 and 5.5 were measured respectively by Martin et al. [6] over a comparable stress-temperature regime.

The temperature dependence of the steady-state creep rate of the Ti-48Al-1Nb is presented in the Arrhenius plots of log steady-state creep rate vs reciprocal absolute temperature $1 / T$ at three stress levels in Fig. 4. The slopes of the plots of Fig. 4 represent the apparent creep activation energy. As indicated in Fig. 4, the apparent creep activation energy of the $\mathrm{Ti}-48 \mathrm{Al}-1 \mathrm{Nb}$ varies from $317.5 \mathrm{~kJ} / \mathrm{mol}$ at $137.8 \mathrm{MPa}$ to $341 \mathrm{~kJ} / \mathrm{mol}$ at $206.8 \mathrm{MPa}$. The results of Fig. 4 again are in very good agreement with the apparent creep activation energy measured for Ti-50.3Al over the same stress-temperature regime

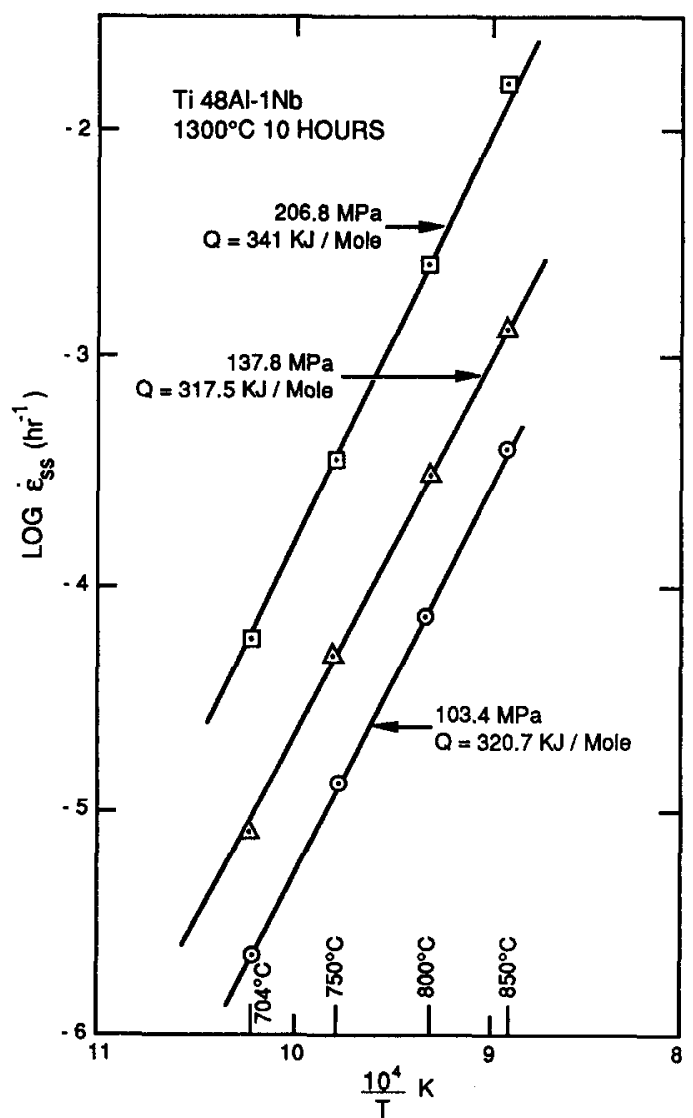

Fig. 4. Arrhenius plots of the temperature dependence of steady-state creep rate of $\mathrm{Ti}-48 \mathrm{Al}-1 \mathrm{Nb}$ at $103.4,137.8$ and $206.8 \mathrm{MPa}$. 
where a value of $300 \mathrm{~kJ} / \mathrm{mol}$ was reported [6]. The apparent creep activation energy measured for the ternary $\mathrm{Ti}-48.7 \mathrm{Al}-2.2 \mathrm{~W}$ alloy was higher at $370 \mathrm{~kJ} /$ mol [6]. Taking an average of the three values reported in the present study, a value of $326.4 \mathrm{~kJ} / \mathrm{mol}$ is found. Within reasonable experimental error in calculation of the slopes, the apparent creep activation energies presented in Fig. 4 can be taken as stress and temperature independent indicating a single rate controlling mechanism for creep deformation of the $\mathrm{Ti}-48 \mathrm{Al}-1 \mathrm{Nb}$ over the stress-temperature regime of the present study. Therefore, in the following discussions, the value of $326.4 \mathrm{~kJ} / \mathrm{mol}$ will be taken as the value of the apparent creep activation energy of the $\mathrm{Ti}-48 \mathrm{Al}-1 \mathrm{Nb}$ of this study.

\section{DISCUSSIONS}

\subsection{Microstructure}

As mentioned briefly in a previous section, an important aspect of the microstructure of the present $\mathrm{Ti}-48 \mathrm{Al}-1 \mathrm{Nb}$ is the shape of the grain boundary between two adjacent lamellar grains. An example of this type of boundary is shown in the micrograph of Fig. 5. We note that the alternating $\gamma / \alpha_{2}$ laths interlock as they meet creating a very irregular or serrated boundary rather than a smooth boundary such as that between an equiaxed $\gamma$ grain and a lamellar grain. Given the importance of grain boundaries in high temperature creep deformation, the serrated boundaries separating adjacent lamellar grains may be an important source of strengthening during creep deformation of two phase $\gamma \mathrm{TiAl}$ heat treated to the duplex microstructure.

In a previous study of the creep deformation of $\mathrm{Al}$ doped $\mathrm{Zn}$ bi-crystals and poly-crystals, Maruyama et al. [9] present evidence of grain boundary effects in the dislocation creep regime. It is generally considered that grain size and thus the boundary area does not play a significant role in creep occurring by dislocation glide and climb in the grain matrix. However, Maruyama et al. have shown that grain boundary sliding can contribute to creep deformation in the

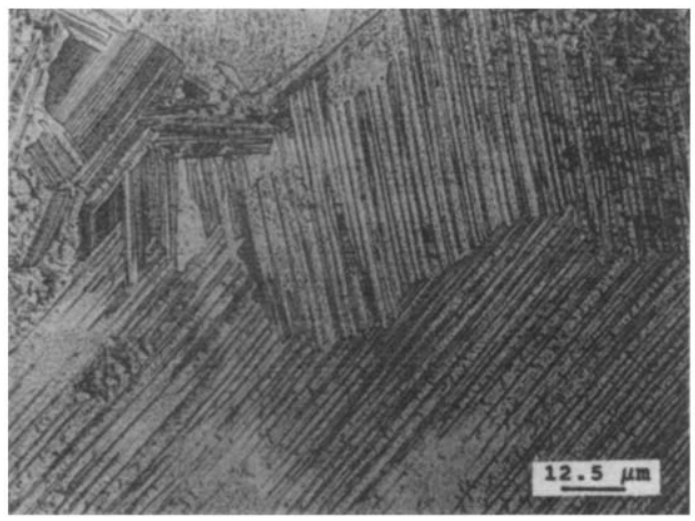

Fig. 5. Optical micrograph showing interlocking $\gamma / \alpha_{2}$ laths at the boundary between two lamellar grains. power law regime (creep controlled by dislocation climb) and that suppression of sliding provides significant strengthening against creep deformation. In their study [9], suppression of grain boundary sliding in the $\mathrm{Zn}$ bi-crystals and poly-crystals was achieved by doping with small amounts of $\mathrm{Al}$ which segregated to the grain boundaries and pinned the boundaries thus suppressing sliding.

In the present case, we envision the suppression of boundary sliding by geometrical strengthening via the interlocking $\gamma / \alpha_{2}$ laths. If this were the case, we would expect an increase in creep resistance with increasing volume fraction of lamellar grains which would be expected to increase the tendency to form the interlocking (serrated) boundaries separating the lamellar grains. It has been suggested that the creep strength of two phase $\gamma \mathrm{TiAl}$ alloys does increase with increasing lamellar structure [7]. Another very important aspect of the microstructure is the scale of the structure specifically in the present case, the width of the $\gamma / \alpha_{2}$ lath. Slip distance which would be dictated by the width of the $\gamma / \alpha_{2}$ laths should exert a substantial influence on creep controlled by dislocation movement. We would expect the steady-state strain rate to decrease with decreasing $\gamma / \alpha_{2}$ lath width (slip distance) as this controls the glide distance. Superimposing a restriction on grain boundary sliding along with a fine $\gamma / \alpha_{2}$ lath width should result in an optimum resistance to high temperature creep. This supports the proposition that a fully transformed (completely lamellar) structure offers the optimum creep resistance for the two phase $\gamma$ TiAl alloys. However, we point out that this microstructure is extremely brittle at room temperature [1].

\subsection{Creep deformation}

As pointed out in the experimental procedure, we have employed the technique of an incremental stress increase on a single specimen at constant temperature in order to generate the present creep data. This method makes the explicit assumption of deformation history independence. That is, the creep deformation of the specimen taking place at $\sigma_{3}$ is not influenced by the creep deformation which occurred at $\sigma_{2}$ and $\sigma_{1}$ previously. This means that a fresh creep specimen loaded initially at a stress level equal to $\sigma_{3}$ of the stress increment specimen at the same temperature, would creep at a rate identical or nearly identical to the rate of the stress increment specimen at $\sigma_{3}$. We have conducted this experiment using the temperature of $800^{\circ} \mathrm{C}$ and stress level $206.8 \mathrm{MPa}$ which is $\sigma_{3}$ at $800^{\circ} \mathrm{C}$. A comparison of the creep behavior of a specimen tested at $800^{\circ} \mathrm{C} / 206.8 \mathrm{MPa}$ to that of the creep behavior at $800^{\circ} \mathrm{C} / \sigma_{3}$ is presented in Fig. 6 . Reviewing the creep results in Table 2 , indicates that the steady-state strain rates of these two creep tests are nearly identical. We take this as evidence of the creep deformation at $\sigma_{3}$ at $800^{\circ} \mathrm{C}$ being independent of the creep deformation which occurred at the two lower stress levels at this temperature. Further 


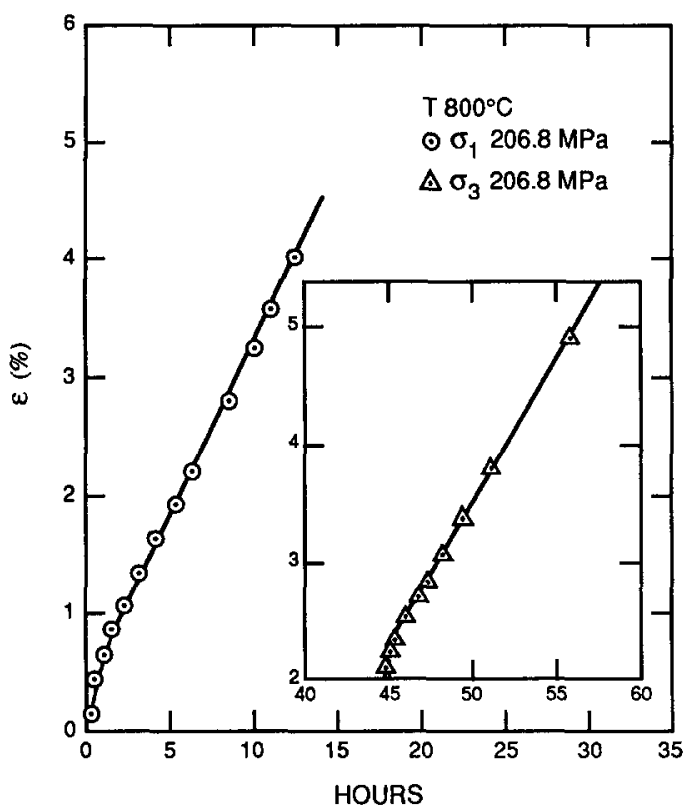

Fig. 6. Comparison of incremental stress creep response $\left(\sigma_{3}\right)$ to creep response of specimen loaded at initial stress $\left(\sigma_{1}\right)$ equal to $\sigma_{3}$ of incremental stress specimen. Condition compared is $800^{\circ} \mathrm{C} / 206.8 \mathrm{MPa}$.

evidence of the stress increment method on a single specimen at constant temperature as being a valid method of generating the present creep data is the excellent agreement between the present results and those of Martin et al. [6] with respect to the stress and temperature dependence of the steady-state strain rates.

From the previous studies on creep deformation of $\gamma$ TiAl alloys [6, 10-12], we can analyze the creep behavior of these materials using existing constitutive equations. For the present creep data the equation

$$
\dot{\varepsilon}_{\mathrm{s}}=A(\sigma)^{n} \exp (-Q / R T)
$$

where $\dot{\varepsilon}_{\mathrm{s}}$ is the steady-state strain rate, $A$ is a structure dependent constant which reflects the influence of stacking fault energy (SFE) [13], $\sigma$ is the applied stress, $n$ is the apparent stress exponent. $Q$ is the apparent creep activation energy, $R$ is the gas constant, and $T$ is the absolute temperature, is used to analyze the creep data. Taking the average value of the apparent creep activation energy of $326.4 \mathrm{~kJ} / \mathrm{mol}$, the temperature compensated steady-state strain rate $\left(\dot{\varepsilon}_{\mathrm{s}} \cdot e^{Q / R T}\right)$ is plotted against the applied stress on $\log -\log$ scales in Fig. 7. As shown in Fig. 7, all of the data collapses onto a single line having a slope equal to 4.95. This value of the stress exponent is in excellent agreement with the value given by the constitutive equations, predicting dislocation climb controlled power law creep [13]. With respect to the temperature dependence, we emphasize that the activation energy for lattice self diffusion in TiAl is not at present known quantitatively. However, we have indirect evidence that the self diffusion value may be on the order of the values measured for creep deformation

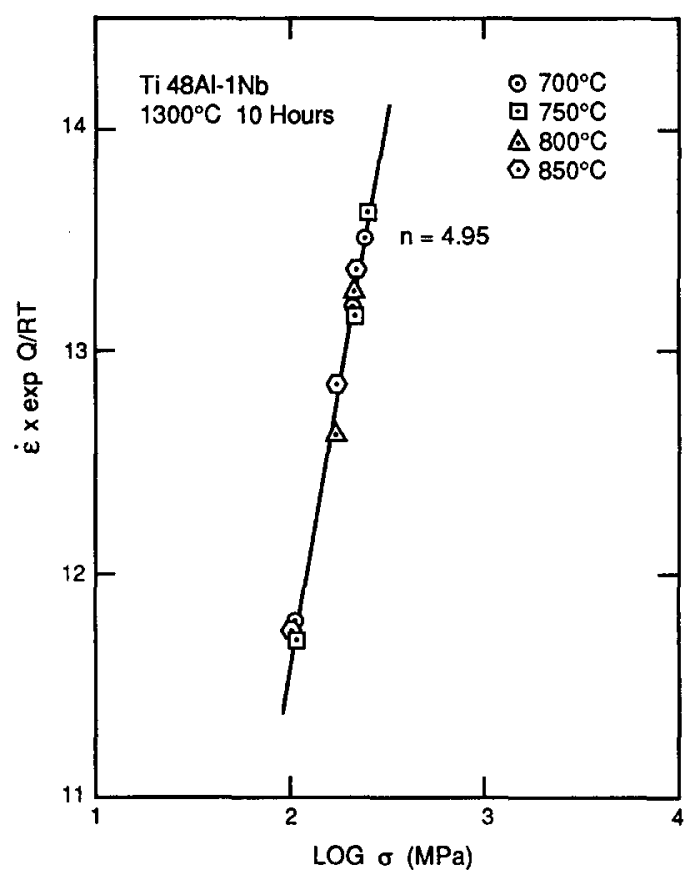

Fig. 7. Temperature compensated steady-state creep rate plotted against applied stress level showing single line collapse of all temperatures. Average apparent creep activation energy of $326.4 \mathrm{~kJ} / \mathrm{mol}$ was used to compensate the steadystate creep rate.

previously $[6,11,12]$ and in the present study. Hayes and Martin [14], have recently measured an apparent activation energy for what at present is believed to be grain boundary diffusion controlled (Coble) creep in a single phase $\mathrm{Ti}-53 \mathrm{Al}-1 \mathrm{Nb} \gamma \mathrm{TiAl}$ alloy. The apparent creep activation energy measured is $192.4 \mathrm{~kJ} /$ mol and corresponds to a temperature-stress regime having a stress exponent equal to unity [14]. Taking as a general rule that the activation energy for grain boundary diffusion is about one-half of the self diffusion activation energy, we have a self diffusion activation energy for $\gamma \mathrm{TiAl}$ on the order of $384 \mathrm{~kJ} /$ mol which is in reasonable agreement with the range of measured values where dislocation climb controlled creep has been suggested $[6,11,12]$. We emphasize that the above discussion does not exclude the need for an accurate knowledge of the actual lattice self diffusion value for these intermetallics, thus making the analysis of creep deformation more quantitative.

It is well established that the stacking fault energy (SFE) is a very important parameter in the assessment of high temperature creep deformation behavior. Sherby and Burke [15] have correlated the SFE with the pre-exponential constant $A$ in the power law creep equation and it is considered that low values of $A$ correspond to materials having a low SFE [15]. Recent fundamental calculations of interatomic potential [16] and charge distribution [17], have indicated that the SFE decreases with decreasing Al concentration in $\gamma$ TiAl. Furthermore, Huang and Hall [1] have pointed out that a minimum in SFE exists within the 48 to 51 at.\% $\mathrm{Al}$ range. From equation (1), 
Table 3. Summary of power law creep constants calculated for several $\gamma$ TiAl compositions

\begin{tabular}{|c|c|c|c|c|c|c|}
\hline $\begin{array}{l}\text { Composition } \\
\text { (at. \%) }\end{array}$ & $\begin{array}{c}\sigma \\
(\mathrm{MPa})\end{array}$ & $\begin{array}{c}T \\
\left({ }^{\circ} \mathrm{C}\right)\end{array}$ & $n$ & $\underset{(\mathrm{kJ} / \mathrm{mol})}{Q}$ & $A$ & Reference \\
\hline $\mathrm{Ti}-48.7 \mathrm{Al}-2.2 \mathrm{~W}^{\mathrm{a}}$ & $173-345$ & $700-900$ & 4.5 & 400 & $2.2 \times 10^{5}$ & {$[12]$} \\
\hline $\mathrm{Ti}-48.7 \mathrm{Al}-2.2 \mathrm{~W}$ & 172.4 & $750-900$ & 5.5 & 370 & $2.83 \times 10^{7}$ & [6] \\
\hline $\mathrm{Ti}-50.3 \mathrm{Al}^{\mathrm{a}}$ & $206-241$ & $700-850$ & 4.0 & 300 & $1.78 \times 10^{7}$ & {$[6]$} \\
\hline $\mathrm{Ti}-48 \mathrm{Al}-1 \mathrm{Nb}^{\mathrm{a}}$ & $103-241$ & $704-800$ & 4.95 & 326.4 & $6.34 \times 10^{7}$ & P.S. \\
\hline $\mathrm{Ti}-53 \mathrm{Al}-1 \mathrm{Nb}^{\mathrm{a}}$ & $69-103$ & $832-900$ & 6.0 & 560 & $3.0 \times 10^{10}$ & [14] \\
\hline
\end{tabular}

the value of the power law creep constant $A$ can be calculated provided the apparent stress exponent and activation energy is known for a given stresstemperature regime in which creep has been measured. In light of some previous observations, regarding creep behavior of a $\mathrm{Ti}-48.7 \mathrm{Al}-2.2 \mathrm{~W}$ alloy [12] and the comparison of the creep behavior of the present $\mathrm{Ti}-48 \mathrm{Al}-1 \mathrm{Nb}$ alloy to that of $\mathrm{Ti}-50.3 \mathrm{Al}$ binary [6], it is of interest to focus some attention on the power law creep constant in order to examine these observations. We will also be able to examine the influence of $\mathrm{Al}$ concentration on the power law creep constant by comparing the $A$ calculated from the present creep data to that determined from tension creep data for a single phase $\mathrm{Ti}-53 \mathrm{Al}-1 \mathrm{Nb}$ alloy generated in a temperature-stress regime believed to correspond to dislocation creep [14]. We will first concentrate on a previous observation. Martin and Lipsitt observed a significant reduction in the steady-state strain rate of the TiAl alloy $\mathrm{Ti}$ 48.7Al-2.2W when the $\mathrm{W}$ was held in solid solution as opposed to previous creep rates measured for the same alloy with the $\mathrm{W}$ precipitated out on internal surfaces in the form of fine beta phase particles [6]. The apparent stress exponents and activation energies for creep deformation were found to be nearly identical for the two conditions. It was concluded that the significant difference in creep resistance could not be explained on the basis of the stress or temperature dependence leaving the pre-exponential constant $A$ as the only remaining variable [12]. Using the creep data for the Ti-50.3Al binary [6] and the data for the $\mathrm{Ti}-48.7 \mathrm{Al}-2.2 \mathrm{~W}$ solid solution [12], we have calculated the power law creep constant $A$ using equation (1). The values of $A$ obtained from the previous studies [6, 12], along with the values obtained from the creep data for the $\mathrm{Ti}-48 \mathrm{Al}-1 \mathrm{Nb}$ of this study as well as the single phase $\mathrm{Ti}-53 \mathrm{Al}-1 \mathrm{Nb}$ alloy, are presented in Table 3. Also included in Table 3 are

†Our assumption of similar microstructure is based only on a comparison of the optical microstructures of the Ti-50.3Al binary and the $\mathrm{Ti}-48 \mathrm{Al}-1 \mathrm{Nb}$ of this study. We recognize that a quantitative comparison of microstructures would require detailed TEM characterization of each alloy. Thus, microstructural details beyond the resolution of optical microscopy could also contribute to the differences in creep resistance observed for these two compositions. the apparent stress exponents and activation energies used in the calculations of $A$.

In reviewing the data listed in Table 3, some interesting features are noted. First, with respect to the previous observations of Martin and Lipsitt [12], we see that holding $\mathrm{W}$ in solid solution results in a significant decrease in $A$ compared to the case where it is precipitated out as a second phase. These observations would tend to support the contention that $\mathrm{W}$ might lower the SFE of $\gamma \mathrm{TiAl}$, thus leading to the observed reduction in steady-state creep rate of the solid solution condition [14]. Although the data given in Table 3 is very limited and must be considered preliminary, we do note that with respect to the $\mathrm{Al}$ concentration, the value of $A$ is significantly higher for the $\mathrm{Ti}-53 \mathrm{Al}-1 \mathrm{Nb}$ composition compared to the two phase $\gamma$ TiAl alloys listed. On a preliminary basis, considering the correlation of $A$ with SFE [15], our results would concur with the proposition that the SFE of $\gamma$ TiAl does decrease with decreasing Al concentration which then may in part explain one aspect of the noted higher creep resistance of the two phase TiAl alloys compared to that of single phase $\gamma$ TiAl.

A comparison of the stress dependence of the steady-state strain rates of the $\mathrm{Ti}-48 \mathrm{Al}-1 \mathrm{Nb}$ alloy, to those of the Ti-50.3Al binary [6], are shown at 704 and $750^{\circ} \mathrm{C}$ in Fig. 8. We are making this comparison on the basis of similar composition and microstructure $\dagger$ of these two $y \mathrm{TiAl}$ alloys. The Ti-50.3Al binary was heat treated such as to produce a duplex microstructure consisting of equiaxed primary $\gamma$ grains along with regions containing the lamellar structure very similar to the microstructure of the present Ti-48Al-Nb alloy. A very interesting feature of the comparison of creep behavior of these two alloys, is the nearly identical apparent creep activation energies and stress exponents measured over an identical stresstemperature regime. However, the creep resistance of the $\mathrm{Ti}-50.3 \mathrm{Al}$ binary is clearly superior to that of the $\mathrm{Ti}-48 \mathrm{Al}-1 \mathrm{Nb}$. In reviewing the data listed in Table 3, it appears that the difference in steady-state creep rate between the Ti-50.3Al binary and the $\mathrm{Ti}-48 \mathrm{Al}-1 \mathrm{Nb}$ may be rationalized on the basis of the lower power law creep constant for the former. This argument is identical to that of Martin and Lipsitt given previously for the difference in steady-state strain rate of the $\mathrm{Ti}-48.7 \mathrm{Al}-2.2 \mathrm{~W}$ alloy in the supersaturated condition (low $\dot{\varepsilon}_{\mathrm{s}}$ ) vs having the $\mathrm{W}$ precipitated out 


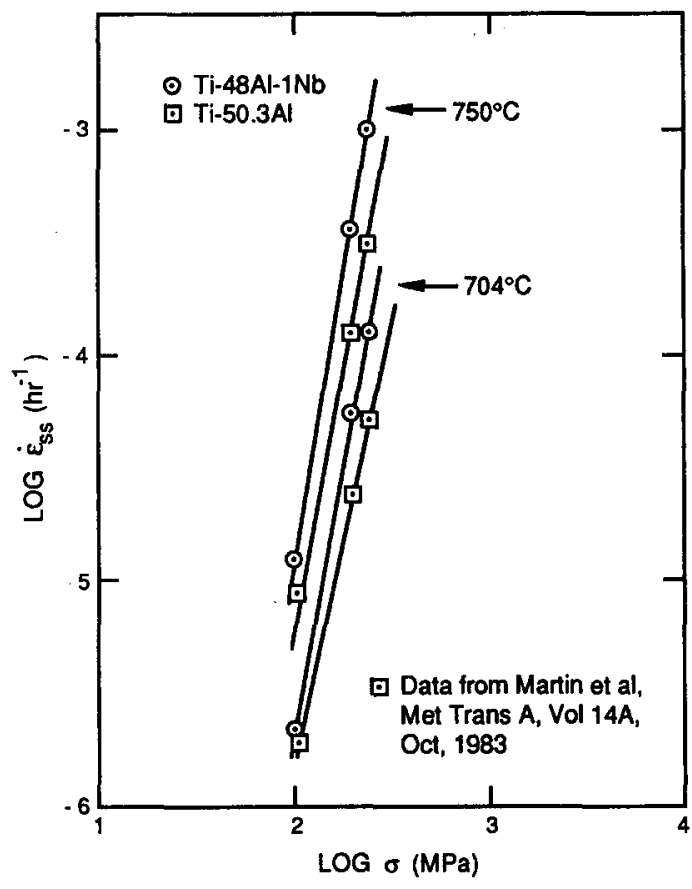

Fig. 8. Comparison of stress dependence of steady-state creep rate of Ti-50.3Al and $\mathrm{Ti}-48 \mathrm{Al}-1 \mathrm{Nb}$ at 704 and $750^{\circ} \mathrm{C}$. Data for Ti-50.3Al replotted from Martin et al., Ref. [6].

(higher $\dot{\varepsilon}_{\mathrm{s}}$ ). Each of these microstructural conditions yielded very similar creep activation energies and stress exponents [12]. Martin and Lipsitt pointed out that a difference in the pre-exponential constant $A$, could result in differing steady-state strain rates without influencing the stress or temperature dependence of the steady-state strain rate. The results given in Table 3 show this to be the case. Thus, the basic creep deformation process remains unaltered, but occurs at different velocities. In keeping with the role of SFE, we can suggest that lowering the SFE (lower $A$ ) reduces the climb velocity by making climb more difficult. If dislocation climb is the rate limiting mechanism, we expect an apparent creep activation energy close to that of self diffusion and a stress exponent in the range of 4-5. With respect to $\gamma \mathrm{TiAl}$, we are not yet in a clear position to quantify the former, but the latter is in excellent agreement with constitutive laws describing climb as the dominant creep mechanism. One last comment with respect to the calculation of the power law creep constant of the $\mathrm{Ti}-50.3 \mathrm{Al}$ binary vs that of the $\mathrm{Ti}-48 \mathrm{Al}-1 \mathrm{Nb}$ alloy. We are not sure what fundamental influence $\mathrm{Nb}$ exerts on the atomic bond nature of the $\mathrm{Ll}_{0}$ structure of TiAl [17]. The results in Table 3, although preliminary, indicate that $\mathrm{Nb}$ may weaken the $\mathrm{TiAl}$ lattice at high temperature with respect to creep deformation resistance. Depending on the influence of $\mathrm{Nb}$ on the atomic bond nature of $\mathrm{TiAl}$, it is possible that $\mathrm{Nb}$ may increase the SFE as suggested by the data in Table 3. Thus, the influence of $\mathrm{Nb}$ may more than offset the influence of $\mathrm{Al}$ (note that decreasing
Al content lowers SFE in $\gamma$ TiAl $[1,16,17])$. At this point, the above discussion with respect to $\mathrm{Nb}$ is speculative and more work is required to quantify the influence of alloy additions such as $\mathrm{Nb}$ and other ternary additions as well with respect to their influence on the high temperature creep behavior of these TiAl alloys.

\section{CONCLUSIONS}

The steady-state creep deformation of a cast $\gamma$ TiAl alloy having the composition $\mathrm{Ti}-48 \mathrm{Al}-1 \mathrm{Nb}$ (at.\%), has been studied over the temperature range 704$850^{\circ} \mathrm{C}$ at applied initial stress levels ranging from 103.4 to $241.3 \mathrm{MPa}$. Under these conditions, the stress exponent for creep was found to be $5.0\left(704^{\circ} \mathrm{C}\right)$, $4.9\left(750^{\circ} \mathrm{C}\right), 4.7\left(800^{\circ} \mathrm{C}\right)$ and $4.46\left(850^{\circ} \mathrm{C}\right)$. The apparent activation energy measured for creep ranged from $317.5 \mathrm{~kJ} / \mathrm{mol}(137.8 \mathrm{MPa})$ to $341.0 \mathrm{~kJ} / \mathrm{mol}$ (206.8 MPa). The average value was calculated to be $326.4 \mathrm{~kJ} / \mathrm{mol}$ and is in good agreement with previous values measured for two phase $\gamma \mathrm{TiAl}$ alloys. Taking the average value of $326.4 \mathrm{~kJ} / \mathrm{mol}$ as the activation energy for creep, the temperature compensated steadystate creep rate plotted against stress on $\log -\log$ scales, yields a value of 4.95 for the stress exponent with all temperatures collapsing onto a single line. This value is in excellent agreement with existing creep models predicting dislocation climb as rate controlling for creep deformation. Indirect evidence based on an activation energy of $192.4 \mathrm{~kJ} / \mathrm{mol}$ measured for suggested grain boundary diffusion controlled (Coble) creep of a single phase $\mathrm{Ti}-53 \mathrm{Al}-1 \mathrm{Nb}$ alloy, indicates that the activation energies measured for creep of $\gamma$ TiAl alloys previously and in the present study, may be on the order of the self diffusion activation energy for $\gamma$ TiAl. This is based on an assumption that grain boundary diffusion has an activation energy of about one-half the self diffusion value. We have pointed out the importance of the grain boundary geometry between two lamellar grains with respect to strengthening against grain boundary sliding which may contribute to creep deformation in the dislocation controlled power law creep regime. The interlocking $\gamma / \alpha_{2}$ laths which make up the boundary separating two lamellar grains, are expected to be very resistant to sliding, thus enhancing creep strength of alloys containing lamellar regions. The difference in creep behavior of some $\gamma$ TiAl alloys has been discussed in terms of the power law creep constant and its correlation to the stacking fault energy.

\section{REFERENCES}

1. S. C. Huang and E. L. Hall, Metall. Trans. 22A, 427 (1991).

2. E. L. Hall and S. C. Huang, J. Mater. Res. 4, 595 (1989).

3. E. L. Hall and S. C. Huang, Acta metall. 38, 539 (1990).

4. C. R. Feng, D. J. Michel and C. R. Crowe, Scripta metall. 22, 1481 (1988). 
5. B. London, Howmet Corporation, private communications (1990).

6. P. L. Martin, M. G. Mendiratta and H. A. Lipsitt, Metall. Trans. 14A, 2170 (1983)

7. Y. W. Kim, JOM 41, 24 (1989).

8. B. Dogan, R. Wagner and P. A. Beaven, Scripta metall. 25, 773 (1991).

9. K. Maruyama, Y. Wananabe and H. Oikawa, Acta metall. 34, 2343 (1986).

10. P. L. Martin, D. H. Carter, R. M. Aikin Sr, R. M. Aikin $\mathrm{Jr}$ and L. Christodoulou, Proc. 4th Int. Conf. on Creep and Fracture of Engineering Materials and Structures (edited by B. Wilshire and R. W. Evans), pp. 265-275. Institute of Metals, London (1990).

11. S. L. Kampe, J. D. Bryant and L. Christodoulou, Metall. Trans. 22A, 447 (1991).
12. P. L. Martin and H. A. Lipsitt, Proc. 4th Int. Conf. on Creep and Fracture of Engineering Materials and Structures (edited by B. Wilshire and R. W. Evans), pp. 225-263. Institute of Metals, London (1990).

13. O. A. Ruano, J. Wadsworth and O. D. Sherby, Acta metall. 36, 1117 (1988).

14. R. W. Hayes and P. L. Martin, unpublished research, Metals Technology, Inc. and Rockwell Science Center (1991).

15. O. D. Sherby and P. M. Burke, Prog. Mater. Sci. 13, 333 (1967).

16. T. Kawabata and O. Izumi, Phil. Mag. A 55, 823 (1987).

17. M. Morinaga, J. Saito, N. Yukawa and H. Adachi, Acta metall. 38, 25 (1990). 